\title{
The Effect of Research-based Music Classroom Assessment Techniques on the Students' Performance in Flute Recorder Education
}

\author{
Almighty C. Tabuena \\ High School Department, Espiritu Santo Parochial School of Manila, Inc., Manila, Philippines
}

Received November 12, 2020; Revised December 15, 2020; Accepted January 28, 2021

\section{Cite This Paper in the following Citation Styles}

(a): [1] Almighty C. Tabuena, "The Effect of Research-based Music Classroom Assessment Techniques on the Students' Performance in Flute Recorder Education," Universal Journal of Educational Research, Vol. 9, No. 1, pp. 145 - 153, 2021. DOI: 10.13189/ujer.2021.090116.

(b): Almighty C. Tabuena (2021). The Effect of Research-based Music Classroom Assessment Techniques on the Students' Performance in Flute Recorder Education. Universal Journal of Educational Research, 9(1), 145 - 153. DOI: 10.13189/ujer.2021.090116.

Copyright $(2021$ by authors, all rights reserved. Authors agree that this article remains permanently open access under the terms of the Creative Commons Attribution License 4.0 International License

\begin{abstract}
This action research study utilized a quasi-experimental design to examine the effect of research-based music classroom assessment techniques on the students' performance in flute recorder education of one group using the pre-test and post-test design. The study used a purposive sampling of 30 eighth grade junior high school students from the eight sections of Espiritu Santo Parochial School of Manila, Inc. The participants were introduced to three research-based music classroom assessment techniques as an academic intervention in their flute recorder music learning such as Instrumental Schematic Processing, Music Concept Memory Exercise, and Five-Letter Name Pitch Memory Test. The results of pre-evaluation and post-evaluation were compared to determine its effect. The results showed that the students had a low performance in the pre-test and there was an increase in the post-test after its utilization with a mean score of 23.00 and a standard deviation of 2.83. The t-value of 12.717 significant at $p<.01$ has a significant difference in the performance of the students in flute recorder education. The computed value of normalized gain was 0.469 inferred to a moderate gain on the students' scores. The research-based music classroom assessment techniques as an academic intervention showed positive implications on the students' music learning and performance in flute recorder education. It could also be used as part of an integral domain in assessment and evaluation of learning intended to introduce the classroom
\end{abstract}

teacher and prospective teacher to those elements of measurement and assessment essentials for effective teaching.

Keywords Classroom Assessment Techniques, Effect, Flute Recorder, Memory Exercise, Memory Test, Music, Schematic Processing

\section{Introduction}

The theoretical basis of this action research study is supported in the provisions and policy guidelines on classroom assessment for the $\mathrm{K}$ to 12 Basic Education Program issued by Department of Education (DepEd), Order No. 8, series of 2015, in which at the heart of this assessment framework is the acknowledgment and deliberate consideration of the learners' zone of proximal development [1], the learning inclusion of classroom assessment techniques.

Classroom assessment techniques are strategies and plans of action educators and teachers in the field use to gauge and measure how well students comprehend and understand key points during a lesson, practical-based learning, or a course. These strategies are meant to be a type of formative assessment that provides teachers to make adjustments or modifications to a lesson based on students' needs. Classroom assessment techniques are 
most generally unanimous, ungraded, and are administered during class periods [2]. In terms of the emergence of the existing education curriculum, the $\mathrm{K}$ to 12 Curriculum, as curriculum initiates new standards and measures in terms of learning (content) and performance, the outcomes must be followed to its new sets of competencies - particular to the cognitive domain of learning as the learner manifests an understanding of basic concepts and processes through appreciation, analysis and performance for his/her self-development, the celebration of his/her Filipino cultural identity and heterogeneity, and development of his/her world vision [3]. The idea of students having specific learning styles has implications, even demands, for teaching strategies; because preferred modes of input and output vary from one individual to another, teachers must use an array of teaching techniques and strategies to effectively satisfy the necessities of individual learners [4]. In this particular situation, individual students may be better suited to learning in a particular way, adapted to the learning environment, using distinctive and unique modes for thinking, relating, and creating [5].

In the Philippines, [6] Memo No. 46 series of 2012 had reminded education policymakers that teachers remain essential to the learning process as a catalyst and facilitators of learning. The teaching of Music in the Junior High School levels entails different assessment methods and techniques within the context of holistic development thus in other subject areas in terms of the cultivation of musical competence and artful skills among students. As an intervention, music classroom assessment techniques grant students a prospect to recognize how they are growing over time. Simultaneously, it determines that their feedback and response can make a difference or improvement in what and how they learn and feel more engaged in the learning process - enhance as active learners or participants rather than inert or passive learners. This study would accommodate teachers to have alternative methods of assessing students' performance and teaching strategies that engage in teacher-student synergy and dynamic class involvement. Also, it would contribute to music teachers' skills in part of measurement and evaluation methods, and make them informed to the scope of their expertise in assessment and evaluation processes. In this process, measurement and evaluation are the means through which the reliable academic performance of the students can be made available to teachers, school administrators, parents, and other concerned individuals, in which evaluation is primarily a teaching tool, rather than a method for giving grades or an after-the-course appraisal.

As part of the framework of the study, on the specificity of the flute recorder educational process, this assessment method follows the $\mathrm{K}$ to 12 curriculum in terms of the following considerations: (a) lesson planning through the outcome-based assessment and design, (b) the $\mathrm{K}$ to 12
Music curriculum guide, and (3) content and performance standard, in which the criteria and indicators of assessment were based as a foundation for planning and choosing the methods in the flute recorder educational process with the aid of musical learning competencies. The identified research-based music classroom assessment techniques were aligned in the content and performance standard of the $\mathrm{K}$ to 12 Music curriculum guide evident in the learning competencies and outcome-based education. In addition, in the flute recorder educational process, a teacher-made summative examination was administered to measure how well students grasp key points in a lesson in determining the effect of the research-based music classroom assessment techniques. In this circumstance, either the research-based music classroom assessment techniques are employed concurrently or sequentially.

The paradigm shift of pedagogical practices as envisioned by the educational system would ensure the more efficient and effective delivery and assessment of music lessons particularly to our students' success in musical learning. Curriculum planners will also aware of the significance of administering and managing formative assessments like classroom assessment techniques in assessing and evaluating students' achievement aside from the summative test which is commonly conducted. The results of this action research can aid administrators to create a plan on how the teachers become aware of the quality of classroom assessment techniques and their application in assessing and evaluating students' performance.

\subsection{Statement of the Problem}

In the preliminary stage of this research, the researcher found out that there was a low final grade in Music in the first quarter. In this particular matter, as an action for the difficulties encountered, the score results of the summative examination for the second quarter were subjected to the pre-evaluation before the implementation of research-based music classroom assessment techniques.

The primary objective of this action research study is to examine the effect of research-based music classroom assessment techniques on the students' performance in flute recorder education. To achieve this objective, the study answered the following specific questions:

- What is the performance of the students before and after the implementation of research-based music classroom assessment techniques in flute recorder education?

- Is there a significant difference between the score of the students before and after the implementation of research-based music classroom assessment techniques in flute recorder education

- What is the gain of average in the score of the students' performance with the intervention of research-based music classroom assessment techniques in flute recorder education? 
- What are the research-based music classroom assessment techniques that might contribute and benefit teachers through assessment and evaluation processes in teaching flute recorder education?

\section{Literature Review}

Assessment of student learning is at the heart of effective teaching [7]. In addition, knowing student performance, identifying what was done well, what has yet to be improved, and providing specific feedback or response to students, [7] pointed that it has the prospective to valuable improvement of the music program in real and significant ways. Assessment data can conform to an integral component of improving any music program if it directs learning outcomes that are comprehensible and concentrate on the characteristics of student performance that are most significant. Considering [8] induced the dynamism of classroom assessment to cultivate students' achievement to a more substantial audience, more research has been conducted on its practical applications and purposes. Leahy et al. [9] equipped teachers with numerous activities to enhance their classroom assessment application. Based on the teachers' demonstrations, these researchers came to approximately 50 assessment "techniques." Common for these techniques is that they blemish the divide between instruction and assessment, and make it feasible to accommodate the teaching while the learning is still taking place.

\subsection{The Philosophy and Objectives of Music Education}

In the preface of the Philippine Society for Music Education (PSME) Curriculum Guide, "Enhancing Musical Growth in the Elementary School," which asserted that the underlying philosophy of the music education program is "fundamentally aesthetic education, intended at supporting the learner cultivate a sensitivity to the artistic attributes of music ... yet further appreciating the ethical, physical, psychological, social, and other values and states of music," [10]. This is in conforming with the fundamental philosophy of music education linked in the Philippine Society for Music Education convocation on "The Goals of Music Education" on the 7 th to 9 th of November, 1975. The role and place of music education in the curriculum are manifested in the following principles: (a) music satisfies the human necessity for the spiritual and aesthetic occurrence; (b) music is part of the cultural legacy (heritage); (c) music is a means for self-expression and creativity; (d) music is an academic and educational discipline and must be acknowledged as such; (e) every individual must be granted an opportunity to adequately strengthen his music potential; and (f) education in music is most contributory to national development by being regarded primarily with the musical (rather) than extra-musical implications and values.

These principles, indeed, worked as a foundation for the general aims of music education in the Philippines at all academic levels, specifically: (a) a lenient program for literacy in music; (b) a wide and varied opportunity for the production, recreation and significant appreciation of music for all; (c) the integral and efficient training of teachers in music; and (d) a definite and positive appreciation for Philippine Music and to the music of other cultures, eras, and practices. Whereas, relevant assessment is employed to guarantee the success of the learners in advancing from guided (with more knowledgable others known as MKO) to an independent (individual) array of knowledge, comprehension, and experiences, and to empower them to shift this favorably in future circumstances. This view also acknowledges the diversity of students inside the classroom, the necessity for multiple methods of measuring their diverging abilities and learning strengths (potentials), and the purpose of learners as co-participants in the evaluation process. Evaluative procedures must be developmentally and culturally appropriate and that their selection is founded on the objectives of an instructional program [11]; if programs for young learners are to be sensitive to their developmental needs, the following standards must be met when formulating the corresponding assessment procedures: (a) objectives encompass all domains, (b) match between curriculum objectives and assessment goals, (c) ongoing, continuous and varied strategies, and (d) developmentally and culturally sensitive.

\subsection{Classroom Assessment in the K-12 Basic Education Program}

High-quality assessment and evaluation of learning can provide substantial and valid information about students' learning outcomes and procure insights into the effectiveness of teachers' instruction. Research shows that teachers who interject formative assessment into their classroom practice can transform substantial achievement gains. Stronge [12] cited a research review written by [8] which analyzed multiple empirical studies to determine whether improvement in classroom assessments can lead to an improvement in learning. They found that informative assessment has substantial positive effects on student achievement, with effect size raging 0.3 to 0.7 standard deviation. In particular, they ascertained that formative evaluation is more efficient for underachievers than for other learners, thus lessening an achievement gap while advancing achievement overall at the corresponding time.

In the Philippines' educational setting, [13] states that assessment shall be used primarily as a quality assurance tool to track students' progress in the attainment of standards, promote self-reflection and personal 
accountability for one's learning, and provide the basis for the profiling of students' performance. According to the Policy Guidelines on Classroom Assessment for the $\mathrm{K}$ to 12 Basic Education Program [14], classroom assessment is an integral part of curriculum implementation. It allows teachers to track and measures learners' improvement and to customize instruction subsequently. Classroom assessment acquaints the learners, as well as their guardians and parents, of their development. Teachers are constantly faced with the challenges and difficulties of evaluating the students' development as well as their teaching effectiveness [15]. Assessment judgments could sustainably improve students' performance; lead the teachers in intensifying the teaching-learning process, and assist policymakers in enhancing the educational system [16]. In response to this challenge, the researcher thought that using formative assessment particularly classroom assessment techniques can improve students' performance in music. Various types of learning assessments exist from which an educator can choose.

The central purpose of classroom assessment is to empower both teachers and their students to improve the quality and status of the classroom learning through an approach that is learner-centered, teacher-directed, mutually beneficial, formative, context-specific, and strongly established in good methods [2]. Angelo and Cross [2] described 50 classroom assessment techniques as simple tools (instruments, forms, strategies, activities) for collecting information on student learning to improve it. Classroom assessment techniques are easy to design, administer, and analyze, and have the added benefit of involving students in their education. They are typically non-graded, anonymous in-class activities that are embedded in the regular work of the class. The 50 classroom assessment techniques are divided into three broad categories: (a) techniques for assessing course-related knowledge and skills; (b) techniques for assessing learner attitudes, values, and self-awareness; and (c) techniques for assessing learner reactions to instruction. Grieve [17] explained that classroom assessment is a continuing advanced feedback mechanism that leads to its distinct implications and indications in terms of the teaching-learning process.

\subsection{Local Studies}

Rosas [18] emphasized the never-ending quest for quality teaching that in the heart of a particular quest to enhance teaching practices is the teacher who might say holds the pivotal factor in the teaching-learning process. The teacher is the most prominent player and decision-maker in the arena where learning takes place and given a good teacher, learning can be made to happen despite deficiencies and insufficiencies in the curriculum, technologically-deprived classroom, inadequacy of instructional materials (e.g. modules, prototype models, quality test, self-learning kits, workbooks) and even with unmotivated learners. The teacher will be able to reconstruct and even transform effectively these impediments into opportunities. Various empirical studies in western countries and the Philippines have shown the relationship between student achievement and teachers' skills, knowledge, and practices. The statements assert that what learners know and can do is critical to what students learning.

Further, in the recent study of [19], the researcher implemented classroom assessment techniques in preparing Basic Piano and World Music instructions. The following are the classroom assessment techniques acquired and executed by the researcher in a large class: Music Concept Memory Exercise, Three-Chord Familiarization Assessment, Instrumental and Vocal Schematic Processing, and Five-Letter Name Pitch Memory Test. Based on the findings, the stated techniques might apply as part of an essential area in the musical learning assessment intended to improve the classroom-prospective educator to the evaluation elements essentials for productive pedagogy.

The objective and philosophy of Music education give a clear direction, outcome, and purpose of assessment in general instructions to assure that proper assessment has been utilized through a diversity of activities of learning outcomes for the holistic development (integral approach) of each learner [20]. Further, planning classroom assessments require determining what is to be measured and then defining it precisely so that tasks can be formed that require the intended learning and competencies, while the method of assessments taking place, reflects various relevant measures in learning outcomes related to music.

\section{Methodology}

\subsection{Research Design}

This action research study employed a quasi-experimental design to examine the effect of research-based music classroom assessment techniques on the students' performance in flute recorder education of one group using the pre-test and post-test design, integrating inferential statistical data analysis, the paired t-test. The mean results of pre-test (pre-evaluation) and post-test (post-evaluation) were compared to determine the effect of music classroom assessment techniques. The difference between the mean score performance of the pre-evaluation and post-evaluation was computed and tested for significant difference, a test of differences of two means taken from the same group ( $t$-test for a dependent sample).

\subsection{Participants of the Study and Research Locale}

The participants of this study were determined through purposive convenience sampling, a specific type of 
non-probability sampling method, which is selected based on convenient accessibility and proximity to the researchers as well as the characteristics of a population and the objective of the study [21]. There were a total of thirty (30) Grade 8 students who were purposively selected from the eight sections of Espiritu Santo Parochial School of Manila, Inc., Manila, Philippines. The participants were chosen which notably got a fairly satisfactory (low) to the satisfactory final grade in Music ranging from 75 to 79 in the first quarter. Table 1 shows the performance of students in Music for the first quarter, while Table 2 shows the frequency distribution of the students for each section.

Table 1. First Quarter Performance of the Students in Music

\begin{tabular}{cccc}
\hline $\begin{array}{c}\text { Performance } \\
\text { Rating }\end{array}$ & Descriptors & Frequency & $\begin{array}{c}\text { Percentage } \\
(\mathbf{\%})\end{array}$ \\
\hline $90-100$ & Outstanding & 0 & 0 \\
$85-89$ & Very Satisfactory & 0 & 0 \\
$80-84$ & Satisfactory & 0 & 0 \\
$75-79$ & Fairly Satisfactory & 30 & 100 \\
Below 75 & Did Not Meet & 0 & 0 \\
\hline \multicolumn{2}{c}{ Expectations } & 30 & 100 \\
\hline \multicolumn{2}{c}{ Total of the Performance Rating } & 77.10 \\
\hline Interpretation & & Fairly \\
\hline
\end{tabular}

Table 1 shows that the students had a fairly satisfactory in their first-quarter performance in Music before the implementation of music classroom assessment techniques with a performance rating mean score of $77.10 \%$. This data was used by the researcher in identifying the participants of the study as indicated in detail below:

Table 2. Frequency Distribution of Grade 8 Students per Section

\begin{tabular}{ccc}
\hline Section & Frequency & Percentage (\%) \\
\hline 8 - Our Lady of Antipolo & 3 & 10 \\
8 - Our Lady of Fatima & 1 & 3.33 \\
8 - Our Lady of Good Counsel & 3 & 10 \\
8 - Our Lady of Guadalupe & 2 & 6.67 \\
8 - Our Lady of La Naval & 6 & 20 \\
8 - Our Lady of Loreto & 7 & 23.33 \\
8 - Our Lady of Lourdes & 5 & 16.67 \\
8 - Our Lady of Manaoag & 3 & 10 \\
\hline Total & $\mathbf{3 0}$ & $\mathbf{1 0 0}$
\end{tabular}

Table 2 shows that the students came from the eight different sections in the eighth grade of the school such as 8 - Our Lady of Antipolo, 8 - Our Lady of Fatima, 8 - Our Lady of Good Counsel, 8 - Our Lady of Guadalupe, 8 Our Lady of La Naval, 8 - Our Lady of Loreto, 8 - Our Lady of Lourdes, 8 - Our Lady of Manaoag. The number 8 before the name of each section means that the classes belong to eighth grade in the junior high school of Espiritu Santo Parochial School of Manila, Inc., Manila Philippines.

\subsection{Intervention and Data Collection Materials}

A teacher-made summative examination (the pre-evaluation and post-evaluation) was subjected and administered in preparation of test items in Music, and teacher-made music classroom assessment techniques, the strategies, and treatment of the researcher, in Music were used to measure how well students grasp key points in a lesson or a course. According to [7], developing, from scratch, assessment procedures along with valid and reliable measures of student achievement is a daunting task to ask of any single teacher; what follows is an attempt to provide both experienced and novice music teachers with ideas of how to more effectively assess our students.

In the intervention implemented as the music classroom assessment techniques, the researcher collected and developed different classroom assessment techniques in Music, and applied the three identified music classroom assessment techniques in the class on the second quarter of the school year, after the pre-evaluation on the first quarter of the school year. The following are the three music classroom assessment techniques used by the researcher among the participants of the study:

Table 3. Research-based Music Classroom Assessment Techniques Intervention in the Study

\begin{tabular}{|c|c|}
\hline Intervention & Description \\
\hline $\begin{array}{c}\text { Music Concept } \\
\text { Memory Exercise }\end{array}$ & $\begin{array}{l}\text { It is a lesson-based classroom assessment } \\
\text { technique in which music concepts are } \\
\text { summarized after a short (specific) lesson } \\
\text { into varied forms (types) of objective test } \\
\text { items such as short-answer items, true-false } \\
\text { or alternative-response items, matching } \\
\text { exercises, multiple-choice items, and } \\
\text { interpretive exercises; in this assessment, it } \\
\text { could be followed by another short lesson } \\
\text { and another exercise. }\end{array}$ \\
\hline $\begin{array}{c}\text { Instrumental } \\
\text { Schematic } \\
\text { Processing }\end{array}$ & $\begin{array}{l}\text { It is a lesson-based classroom assessment } \\
\text { technique in which certain musical } \\
\text { instruments are classified based on } \\
\text { Hornbostel-Sachs Classification of } \\
\text { Musical Instruments in accordance to their } \\
\text { (students) schema (background } \\
\text { knowledge); in this process, it can be used } \\
\text { as a cognitive shortcut - allowing the most } \\
\text { common explanation to be chosen for new } \\
\text { information. }\end{array}$ \\
\hline $\begin{array}{l}\text { Five-Letter Name } \\
\text { Pitch Memory Test }\end{array}$ & $\begin{array}{l}\text { It is a flute recorder-based classroom } \\
\text { assessment technique in which the } \\
\text { researcher used the letter name pitch } \\
\text { instead of so-fa name pitch (notes) in } \\
\text { teaching flute recorder; in this process, the } \\
\text { student will point five positions on the flute } \\
\text { recorder (or dummy flute known as } \\
\text { bamboo flute recorder) to test their pitch } \\
\text { (letter name) recognition. }\end{array}$ \\
\hline
\end{tabular}

On the other hand, the researcher inquired the aid of 
three (3) experts/experienced coordinators and teachers in the validation process of the test items (content and face validity) before the pre-evaluation (pre-test) took place in the selected research locale. The validation instrument is composed of 14 items which are arranged in terms of (a) format and design, (b) objectives, (c) content, and (d) language. Table 3 shows the rating scale used in the validation of the instrument.

Table 4. Rating Scale Used in the Validation of the Instrument

\begin{tabular}{ccc}
\hline Scale & Range & Interpretation \\
\hline 5 & $4.21-5.00$ & Very Acceptable \\
4 & $3.41-4.20$ & Acceptable \\
3 & $2.61-3.40$ & Moderately Acceptable \\
2 & $1.81-2.60$ & Fairly Acceptable \\
1 & $1.00-1.80$ & Not Acceptable \\
\hline
\end{tabular}

In terms of the format and design of the instrument, the obtained value of the weighted mean among the three validators was 4.50 interpreted as very acceptable; in terms of the objective, 4.67 interpreted as very acceptable; in terms of the content, 4.42 interpreted as very acceptable; and in terms of the language, 3.89 interpreted as acceptable. The overall rating of the instrument was 4.37 interpreted as very acceptable. In this case, the instrument for this study is very acceptable and valid.

\subsection{Data Gathering Procedure}

The stages used in this study were based on the stages detailed by [22], and the instructional design developed by [23]: Stage I, Planning Stage; Stage II, Development Stage; Stage III, Implementation Stage; and Stage IV, Evaluation Stage.

In the Planning Stage, the K-12 Music Curriculum Guide was applied as a foundation for the content and performance standard, and learning competencies in direction to the validity of the classroom assessment, as well as to reference materials that will supplement the content's context and learning. The music classroom assessment techniques used were divided into two: (a) Instrumental Music Lesson, and (b) Flute Recorder Music. Classroom assessment techniques for the Instrumental Music Lesson Instructions include Music Concept Memory Exercise and Instrumental Schematic Processing; for Flute Recorder Music Instructions include Five-Letter Name Pitch Memory Test.

In the Development and Implementation Stage, the researcher devised approaches and procedures to assess how well students grasp key points in a lesson or a practical-based course. These developed strategies, the research-based music classroom assessment techniques, were being implemented after the pre-test (pre-evaluation).
The following are the research-based music classroom assessment techniques executed by the researcher in a large class to provide and encourage other teachers, music or non-music teachers, through assessment and evaluation processes in teaching the flute recorder education: (a) Music Concept Memory Exercise, a lesson-based classroom assessment technique, (b) Instrumental Schematic Processing, a lesson-based classroom assessment technique in which certain musical instruments are classified based on Hornbostel-Sachs Classification of Musical Instruments, and (c) Five-Letter Name Pitch Memory Test, a flute recorder-based classroom assessment technique.

The intervention happened during the second quarter of the school year at Espiritu Santo Parochial School of Manila, Inc., Manila, Philippines after the preliminary assessment in the first quarter of the school year. During the implementation, the research-based music classroom assessment techniques were applied one at a time in an entire class period during the Music subject. The following are some of the outline examples of the implementation of research-based music classroom assessment techniques:

Music Concept Memory Exercise - Major Concept: East Asian Music; Sub-Concept: Folk Music; and Music Concept Memory Exercise (assessment method): Matching Exercise

Instrumental Schematic Processing - Major Concept: East Asian Music; Sub-Concept: Korean Musical Instruments; Instrumental Schematic Processing (assessment method): Hornbostel-Sachs Classification

Five-Letter Name Pitch Memory Test - The teacher will integrate first the lesson aligned to flute recorder music. After the lesson, the teacher will ask to play five pitches successively on the student's flute recorder. This assessment technique should not exceed twenty seconds for each student to cater to the large class size. Each pitch should not be followed by its previous or next pitch (e.g. the letter name is $A$, the next letter name should not $G$ the previous pitch, and B - the next pitch). Further, the teacher could create an undefined or defined word using the letter name for better pitch memory recognition of the student/s. Repeat the process to each student before the examination proper. In this case, the remaining time could be the introduction to another familiarization assessment. Lastly, the end of the class routine.

In the last stage, the Evaluation Stage, the researcher used the paired sample t-Test (dependent sample) to determine the effect of the research-based music classroom assessment techniques, and the Hake factor analysis to interpret and analyze the gain in the scores in terms of the performance of the students in Music. 


\subsection{Data Analysis}

The data are analyzed using the frequency, percentage a proportion concerning a whole which is usually the amount per hundred and often denoted using the sign percent (\%) to describe the data vividly), and mean - the average of the scores. Further, the data are analyzed using the paired sample t-test, the results of the pre-test (pre-evaluation) and post-test (post-evaluation) were compared to determine the effect of research-based music classroom assessment techniques on the performance of the students in Music - flute recorder education. Hake factor analysis is also used to obtain the normalized gain in analyzing and interpreting the gain in the scores of the students from the first quarter (pre-evaluation) to the second quarter (post-evaluation). The researcher obtained the value of normalized gain (gain of average) to interpret and analyze the gain in the scores of the students in Music. Hake [24] advocated using normalized gain, in this case, research-based music classroom assessment techniques, for "a consistent analysis over diverse student populations with widely varying initial knowledge states;" that is, it appeared to be independent of population or pre-test scores, allowing instructors to compare their students' learning to those of other students at very different kinds of institutions [25].

\section{Results and Discussions}

\subsection{Performance of the Students on the Implementation of Research-based Music Classroom Assessment Techniques}

Table 5. Performance of the Students in the Pre-evaluation

\begin{tabular}{cccc}
\hline $\begin{array}{c}\text { Performance } \\
\text { Rating }\end{array}$ & Descriptors & Frequency & $\begin{array}{c}\text { Percentage } \\
(\%)\end{array}$ \\
\hline $90-100$ & Outstanding & 0 & 0 \\
$85-89$ & Very Satisfactory & 0 & 0 \\
$80-84$ & Satisfactory & 5 & 16.67 \\
$75-79$ & Fairly Satisfactory & 10 & 33.33 \\
Below 75 & Did Not Meet & 15 & 50 \\
\hline \multicolumn{4}{c}{ Total } \\
\hline Mean (Average of the Test Scores) & 16.80 & 100 \\
\hline Mean of the Transmuted Performance Rating & 56 \\
\hline Interpretation & Did Not Meet Expectations \\
\hline Note. ${ }^{1}$ Department of Education Order No. 8, s. 2015
\end{tabular}

Table 5 reveals that the students had a low performance in the pre-evaluation before the implementation of research-based music classroom assessment techniques with a mean of $56 \%$.

There was an increase in the students' performance in the post-evaluation after the implementation of research-based music classroom assessment techniques with a mean of $76.67 \%$ as shown in Table 6 .

Table 6. Performance of the Students in the Post-evaluation

\begin{tabular}{|c|c|c|c|}
\hline $\begin{array}{c}\text { Performance } \\
\text { Rating }\end{array}$ & Descriptors & Frequency & $\begin{array}{c}\text { Percentage } \\
(\%)\end{array}$ \\
\hline $90-100$ & Outstanding & 8 & 26.67 \\
\hline $85-89$ & Very Satisfactory & 10 & 33.33 \\
\hline $80-84$ & Satisfactory & 6 & 20 \\
\hline $75-79$ & Fairly Satisfactory & 6 & 20 \\
\hline Below 75 & $\begin{array}{l}\text { Did Not Meet } \\
\text { Expectations }\end{array}$ & 0 & 0 \\
\hline & otal & 30 & 100 \\
\hline Mean (Averag & of the Test Scores) & 23.00 & 76.67 \\
\hline \multicolumn{3}{|c|}{ Mean of the Transmuted Performance Rating ${ }^{1}$} & 85 \\
\hline \multicolumn{3}{|l|}{ Interpretation } & $\begin{array}{c}\text { Very } \\
\text { Satisfactory }\end{array}$ \\
\hline
\end{tabular}

Note. ${ }^{1}$ Department of Education Order No. 8, s. 2015

Table 7. Pre-evaluation and Post-evaluation Performance of the Students in Music

\begin{tabular}{ccccc}
\hline Variables & $\begin{array}{c}\text { Mean } \\
\text { (Average of } \\
\text { the Test } \\
\text { Scores) }\end{array}$ & Percentage & N & $\begin{array}{c}\text { Standard } \\
\text { Deviation }\end{array}$ \\
\hline Pre-evaluation & 16.80 & $56.00 \%$ & 30 & 3.25 \\
Post-evaluation & 23.00 & $76.67 \%$ & 30 & 2.83 \\
\hline
\end{tabular}

From Table 5 and Table 6, Table 7 reveals that the students had a low performance in the pre-evaluation before the implementation of research-based music classroom assessment techniques with a mean of 16.80 $(56.00 \%)$, transmuted to a performance rating of $74 \%$ with a remark of "Failed" and a descriptor of "Did Not Meet Expectations" including a standard deviation of 3.25. There was an increase in the students' performance in the post-evaluation after the implementation of research-based music classroom assessment techniques with a mean of $23.00(76.67 \%)$, transmuted to a performance rating of $85 \%$ with a remark of "Passed" and a descriptor of "Very Satisfactory" including a standard deviation of 2.83 .

\subsection{Significant Difference between the Score of the Students}

Table 8. Paired Sample t-test in Music

\begin{tabular}{ccccc}
\hline Variables & $\begin{array}{c}\text { Mean } \\
\text { (Average) } \\
\text { Difference }\end{array}$ & t-value & $\begin{array}{c}\text { Significant } \\
\text { Value }\end{array}$ & $\begin{array}{c}\text { Decision } \\
\mathbf{H}_{\mathbf{O}}\end{array}$ \\
\hline $\begin{array}{c}\text { Pre-evaluation } \\
\&\end{array}$ & 6.200 & 12.717 & 2.462 & Rejected \\
\begin{tabular}{c} 
Post-evaluation \\
\hline
\end{tabular}
\end{tabular}

Note. $\mathrm{N}=30 ; \mathrm{df}=29 ; \mathrm{p}<.01$

Table 8 shows the value of $t$ of 12.717 (12.72). The result is significant at $\mathrm{p}<.01$. The result showed that there is a significant difference in the performance of students in music learning of the flute recorder education before 
and after the implementation of research-based music classroom assessment techniques. The mean difference in the mean score was 6.200. In addition, the computed $t$ is greater than the tabular $t$ of 2.462 , thus the hypothesis of no difference in mean scores before and after the implementation of research-based music classroom assessment techniques is rejected.

\subsection{The Gain of Average in the Score of the Students' Performance}

From Table 7, in terms of the pre-test and post-test percentage, the computed value of normalized gain (gain of average) using the Hake factor analysis was 0.469 inferred to a moderate gain in scores of the students in music learning with the use of research-based music classroom assessment techniques in flute recorder education. Table 9 shows the range and inference in the gain of average by [24].

Table 9. The Gain of Average (Normalized Gain)

\begin{tabular}{cc}
\hline Range & Inference \\
\hline $0.000-0.230$ & Low Gain \\
$0.231-0.519$ & Moderate Gain \\
$0.520-$ above & High Gain \\
\hline
\end{tabular}

\subsection{Music Classroom Assessment Techniques in Flute Recorder Education}

The identified research-based music classroom assessment techniques such as (a) Music Concept Memory Exercise, (b) Instrumental and Vocal Schematic Processing, and (c) Five-Letter Name Pitch Memory Test provide and help teachers through assessment and evaluation processes in Music. The aforementioned research-based music classroom assessment techniques could also be used as part of an integral domain in assessment and evaluation of learning intended to introduce the classroom teacher and prospective teacher to those elements of measurement and assessment essentials for effective teaching

\section{Conclusions and Implications}

The students had a low performance in the preliminary pre-evaluation before the implementation of research-based music classroom assessment techniques with a remark of "Failed" and a descriptor of "Did Not Meet Expectations." There was an increase in the students' performance in the post-test after the implementation of research-based music classroom assessment techniques with a remark of "Passed" and a descriptor of "Very Satisfactory." As the results indicated, there is a significant difference in the performance of students in music learning before and after the implementation of research-based music classroom assessment techniques. The computed $\mathrm{t}$-value is greater than the tabular $\mathrm{t}$ significant value, thus the hypothesis of no difference in mean scores before and after the implementation of research-based music classroom assessment techniques is rejected. Further, the value of normalized gain using the Hake factor analysis inferred to a moderate gain in scores of the students in Music learning with the use of research-based music classroom assessment techniques.

The identified research-based music classroom assessment techniques such as (a) Music Concept Memory Exercise, (b) Instrumental Schematic Processing, and (c) Five-Letter Name Pitch Memory Test provide and help teachers through assessment and evaluation processes in Music. The aforementioned research-based music classroom assessment techniques could also be used as part of an integral domain in assessment and evaluation of learning intended to introduce the classroom teacher and prospective teacher to those elements of measurement and assessment essentials for effective teaching.

Foundation in assessment and evaluation of learning and teaching performs a meaningful role in effective teaching, a systematic process that engages analysis and interpretation of data acquired through certain measures to render direction for the instructional process [26]. These research-based assessments and evaluation techniques can also help teachers recognize the ways their students learn the best as well as alert teachers when a certain teaching approach is not working very well. Other benefits include flexibility and timeliness. Many of the research-based classroom assessment techniques, although not all, can be used in a variety of forms and ways. They can be accommodated to fit large or small class sizes, or modified depending on what subject matter is being taught; they can be used to assess students' recall or critical thinking skills [27].

According to [28], to plan and make instruction that is appropriate for individual students or groups of students, it is necessary to understand the factors that influence student performance in class. This means going beyond the assessment of achievement. Chastain [29] believes that teachers need to evaluate constantly their teaching based on student reaction, interest, motivation, preparation, participation, perseverance, and achievement. The conclusions drawn from such an evaluation constitute their main source for measuring the effectiveness of selected learning activities.

\section{Recommendations}

In light of the findings of the study, the researchers recommended to use research-based classroom assessment techniques to gather immediate feedback and to assess the students' learning and effectiveness of teaching practices; find out through an assessment and evaluation of other research-based classroom assessment techniques that 
might help to improve instruction in the teaching-learning process, in which through classroom assessment techniques, it is a better alternative assessment tool compare to the traditional formative and/or summative test; the teacher should have enough background on how to use formative assessments; venture the different kinds of learners and connect it with the possible teaching assessments in a specific grade level to fully comprehend which assessment complements a type of learners, and further evaluate the practices for research-based classroom assessment techniques to be developed and implemented for effective teaching and better learning.

\section{REFERENCES}

[1] S. L. Vygotsky, Mind in society: The development of higher psychological processes. Cambridge: Harvard University Press, 1978.

[2] T. A. Angelo, and P. P. Cross, Classroom assessment techniques: a handbook for college teacher, 2nd ed. San Francisco: Jossey-Bass, 1993.

[3] Department of Education, $K$ to 12 music curriculum guide (grade 1 to grade 10). Pasig City: Department of Education, 2016.

[4] Francis Xavier Engineering College, Teaching \& learning process. Tamil Nadu India: Francis Xavier Engineering College, 2017.

[5] Sambhram Institute of Technology, Teaching-learning process. Jalahalli East, Bangalore, India: Sambhram Institute of Technology, 2017.

[6] Commission on Higher Education. CHED Memorandum Order 46 s. 2012, Policy-Standard to Enhance Quality Assurance (QA) in Philippine Higher Education through an Outcomes-Based and Typology-Based QA. Quezon City, Philippines: Commission on Higher Education, 2012.

[7] P. Hamlin, Music assessment strategies. Boulder, CO, USA: The Music Educator Blog, SmartMusic, 2017.

[8] P. Black, and D. Wiliam, "Assessment and classroom learning," Assessment in Education: Principles, Policy \& Practice, Vol. 5, No. 1, 7-74, 1998.

[9] S. Leahy, C. Lyon, M. Thompson, and D. William, "Classroom assessment: Minute by minute, day by day," Assessment, Vol. 63, No. 3, 2005.

[10] A. C. Atabug, A philosophical basis for music in teacher education, The Philippine Society for Music Education Retrospect. Manila, Philippines: Philippine Society for Music Education, 1975.

[11] D. S. Strickland, and L. M. Morrow, "Assessment and early literacy," The Reading Teacher, Vol. 42, No. 8, pp. 634-635, 1989.

[12] J. H. Stronge, Evaluating what good teachers do. New York: Eye on Education, Inc., 2010.

[13] Department of Education. DepEd Order No. 73, s. 2002,
Guidelines on the Assessment and Rating of Learning Outcomes under the K to 12 Basic Education Curriculum. Pasig City: Department of Education, 2002.

[14] Department of Education. DepEd Order No. 8, s. 2015, Policy Guidelines on Classroom Assessment for the K to 12 Basic Education Program. Pasig City: Department of Education, 2015.

[15] Department of Education. DepEd Order No. 79, s. 2003, Assessment and Evaluation of Learning and Reporting of Students' Progress in Public Elementary and Secondary Schools. Pasig City: Department of Education, 2003.

[16] R. DG. Santos, Assessment of learning 1. Quezon City, Philippines: Lorimar Publishing, Inc., 2007.

[17] D. Greive. A handbook for adjunct/part-time faculty and teachers of adults, 5th ed. The Adjunct Advocate, Ann Arbor, 2003.

[18] R. V. Rosas, "The effect of creative arts on the self-expression of the elementary pupils of Holy Trinity Academy," MA Thesis, Philippine Normal University, Manila, 2010.

[19] A. C. Tabuena, "Effectiveness of classroom assessment techniques in improving performance of students in music and piano," Global Researchers Journal, Vol. 6, No. 1, pp. 68-78, 2019.

[20] A. C. Tabuena, "A literature review on the construction of a teacher-made assessment tool in music listening response competency for junior high school $\mathrm{K}$ to 12 music curriculum," The International Journal of Humanities and Social Studies, Vol. 8, No. 4, pp. 157-163, 2020.

[21] A. C. Tabuena, J. E. M. Bartolome, and D. Taboy, "Preferred teaching practices among junior high school teachers and its impact towards readiness of grade seven students in the secondary school," International Journal of Trend in Scientific Research and Development, Vol. 4 No. 4, pp. 588-596, 2020.

[22] C. Sevilla, et al., An introduction to research methods. Manila, Philippines: Rex Book Store, 1984.

[23] D. O. Aguirre Jr., and G. B. de Cadiz, Instructional materials development manual. Eastern Visayas State University, Tacloban City, 2013.

[24] R. R. Hake, "Interactive-engagement versus traditional methods: A six-thousand-student survey of mechanics test data for introductory physics courses," American Journal of Physics, Vol. 66, No. 1, pp. 64-74, 1998.

[25] S. McKagan, et. al. Normalized gain: What is it and when and how should I use it? PhysPort, 2017.

[26] R. L. Linn, and N. E. Gronlund, Measurement and assessment in teaching. Upper Saddle River, New Jersey: Prentice-Hall, Inc., 2000.

[27] M. Miller, “A teacher's guide to classroom assessment techniques," Journal on Best Teaching Practices, pp. 16-19, 2016.

[28] G. Genesee, and J. Upshur, Classroom-based evaluation in second language education. Cambridge University Press, 1996.

[29] K. Chastain, Developing second language skills. HBJ, Publishers, 1988. 